\title{
Fidelity to law: How Bram Fischer illuminates a perennial debate
}

\author{
KATE O’REGAN* \\ Bonavero Institute of Human Rights, University of Oxford
}

This is the text of the 2016 Bram Fischer Memorial Lecture, delivered at Rhodes House, Oxford, on 27 October 2016. These Memorial Lectures honour Bram Fischer QC, a South African lawyer who defended Nelson Mandela and other leaders of the liberation movement when on trial for their lives, and who himself died in imprisonment in 1975. The 2016 Lecture discusses the themes of the famous Hart-Fuller debate and considers them in light of Bram Fischer's life, in particular his membership of the Communist Party, his estreatment of bail, and his opposition to his consequent disbarring. The Lecture is reproduced here with the kind permission of its organisers, Lord Joel Joffe and Prof Nic Cheeseman, and appears as it was delivered, with only minor editorial changes.

Keywords: Bram Fischer Memorial Lecture; South Africa; apartheid; fidelity to law; HLA Hart; Lon Fuller.

\section{Introduction}

I did not know Bram Fischer. I started studying law in Cape Town in 1977, two years after Bram died. Yet, throughout my legal career Bram’s presence as a lawyer has been palpable. His law reports formed the basis of the library at the Legal Resources Centre, each book stamped with his name. My colleague, Arthur Chaskalson, worked at Bram's desk both when he was Director of the Legal Resources Centre, and when he served as the first President of the Constitutional Court, and then as South Africa's Chief Justice. One of the artworks in the Constitutional Court's famous collection, a handspring puppet, is holding Bram's battered leather briefcase, provided to the artist, William Kentridge, by his father, Sydney. These fragments of Bram's life are continual reminders of his life and his career in the law. But Bram was present too in collegial conversation, especially at the Constitutional Court. Many of my colleagues had been his close friends and colleagues: Arthur Chaskalson, Ismail Mahomed, Sydney Kentridge and Johann Kriegler. Stories about Bram abounded. How much of legal life is story-telling! And how much of the law, and what it stands for, is communicated by these stories.

I am going to start by identifying some of the perennial themes of a great jurisprudential debate that took place at a key time in South Africa's legal history. And then I am going to look at those themes through the prism of Bram's life. In particular, I am going to consider them in the light of Bram's prosecution for being a member of the Communist Party in 1964,

catherine.oregan@law.ox.ac.uk 
his decision at the beginning of 1965 to estreat his bail and go underground, and his opposition to the application to strike him from the roll of advocates later in the same year.

In preparing this address, I was struck by Avishai Margalit's distinction between styles of philosophers:

There are two styles of philosophers: e.g. philosophers and i.e. philosophers-illustrators and explicators. Illustrators trust, first and foremost, striking examples, in contrast with explicators who trust, first and foremost, definitions and general principles. Explicators may use examples, but their examples are stylized and are more like those that appear after i.e. than the genuine examples that follow e.g. The illustrators, for their part, run the risk of using examples as little anecdotes that serve no philosophical purpose. The dangers of each style are clear and almost unavoidable; yet, I believe that style in philosophy matters greatly. When examples are apt, they are illuminations, not just didactic illustrations. When definitions are good, they are explications, not mere stipulations. I see merit in both styles, but by temperament if not by conviction I subscribe to e.g. philosophy. ${ }^{1}$

The style of this lecture is thus e.g. philosophy, using those moments in Bram's life to help us think about important jurisprudential questions raised by an iconic debate.

\section{The Hart-Fuller debate}

The jurisprudential debate to which I refer is of course the famous debate between Herbert Hart and Lon Fuller that began with Professor Hart's delivery of the Oliver Wendell Holmes lecture in April 1957, far from South Africa at Harvard University in Cambridge, Massachusetts. Professor Hart was invited to Harvard to deliver the lecture by Professor Fuller, then Carter Professor of General Jurisprudence at Harvard. Professor Fuller attended the lecture, and in Nicola Lacey's wonderful biography of Hart she records that Joel Feinberg remembered Professor Fuller pacing 'back and forth at the back of the lecture hall like a hungry lion'. ${ }^{2}$ Professor Fuller demanded the right to respond to the lecture and that response was published in the Harvard Law Review, just as Professor Hart’s lecture was. ${ }^{3}$

1 Avishai Margalit, The Ethics of Memory (Harvard University Press 2002) ix, cited in Martin Krygier, 'The Hart-Fuller Debate, Transitional Societies and the Rule of Law' in Peter Cane (ed), The Hart-Fuller Debate in the Twenty-First Century (Hart Publishing 2010) $110 \mathrm{fn} 5$.

2 Nicola Lacey, A Life of HLA Hart: The Nightmare and the Noble Dream (Oxford University Press 2004) 197.

$3 \quad$ HLA Hart, 'Positivism and the Separation of Law and Morals' (1958) 71 Harvard Law Review 593; Lon L Fuller, 'Positivism and Fidelity to Law_A Reply to Professor Hart' (1958) 71 Harvard Law Review 630. 
This debate has become a key reference point of modern common-law jurisprudence. Law students all over the English-speaking world read it and it has generated a small avalanche of commentary and analysis. A Google Scholar search on 23 October 2016 for Hart's paper suggested that it had been cited in 3,357 scholarly articles, while Fuller's article had been cited 1,908 times. $^{4}$

Why would this be? Nicola Lacey has identified three key reasons that contribute to the debate's enduring relevance. ${ }^{5}$ First, there is the intellectual interest and merit of the debate (something I shall return to in a minute). Secondly, there is the fact of 'the sharp joinder of issue $^{6}$ on a matter of contemporary importance at the time, particularly the discussion of the validity of Nazi law. Thirdly and more prosaically, yet nevertheless influentially, there is the fact that the debate was published in an influential journal, the Harvard Law Review, and that by the standards of much academic writing the contributions are relatively short, which renders it a useful teaching resource.

There is a fourth reason, I think. One of the most striking aspects of the debate is that there is a tussle between Hart and Fuller as to the terms of their engagement. The title of Hart's lecture is 'Positivism and the Separation of Law and Morals'. ${ }^{7}$ In it he sought to defend the proposition that the validity of law is and should be separate from the question of its moral status. ${ }^{8}$ The title of Fuller's rebuttal on the other hand is 'Positivism and Fidelity to Law-A Reply to Professor Hart'. Fuller commences by defining 'one of the chief issues' approached by Hart as 'how we can best define and serve the ideal of fidelity to law'. ${ }^{9}$ Yet Fuller's characterisation of fidelity to law as 'one of the chief issues' of Hart's argument is not an

4 Professor Lacey did a similar exercise in mid-2008 producing similar but not entirely consistent numbers: Nicola Lacey, 'Out of the "Witches' Cauldron"? Reinterpreting the Context and Reassessing the Significance of the Hart-Fuller Debate’ in Cane (n 1) 2.

5 Nicola Lacey, 'Philosophy, Political Morality, and History: Explaining the Enduring Resonance of the HartFuller Debate’ (2008) 83 New York University Law Review 1059, 1060-61.

$6 \quad$ ibid 1060.

7 See $n 3$ above.

8 Although some commentators sometimes express doubt as to whether Hart's argument is a normative one, in my view, there can be little doubt that it is. He says in Part IV of his article, for example, that 'I have endeavoured to show that, in spite of all that has been learned and experienced since the Utilitarians wrote, and in spite of the defects of other parts of their doctrine, their protest against the confusion of what is and what ought to be law has a moral as well as an intellectual value'. See Hart (n 3) 621.

$9 \quad$ Fuller, 'Positivism and Fidelity to Law' (n 3) 632. 
obvious sequitur from Hart's lecture. Hart did not use the phrase 'fidelity to law' nor did he explicitly explore what fidelity to law might entail.

The different titles of their articles indicate that Hart and Fuller were concerned with different jurisprudential questions. Hart was firmly concerned, as an analytical positivist, with conceptual questions about law, understood as a system of rules. Fuller on the other hand was not. Although he chose to engage with Hart on Hart's terrain, Fuller was generally concerned with a different jurisprudential agenda. He adopted different definitions of law in the course of his career but all of them were dynamic (and distinctly not definitions within the analytical positivist tradition)_eg " "law" means the life work of the lawyer', ${ }^{10}$ and 'law is the enterprise of subjecting human conduct to the governance of rules'.${ }^{11}$ Law for Fuller was an activity, not simply a set of rules. Robert Summers has aptly characterised Hart's approach, that of legal positivism, as 'anatomy', and Fuller's approach, focusing as he did on institutional processes and actors, as 'physiology'. ${ }^{12}$ This sense of a conversation where the participants are not quite talking the same language is, I think, one of the reasons for the enduring fascination of the debate. For the shifting terms of engagement continually suggest ways in which the debate can be reframed and reinterpreted.

The debate traverses several important issues but the one I want to explore more fully is the discussion of Nazi law. The debate centred on the questions whether immoral laws that had been enacted by the Nazis were valid laws, and how German courts in the post-war era should treat those laws. These two questions, it will be immediately obvious, have great resonance for South African lawyers. For South Africa, like Germany, has a legal system that was defiled by racist exclusion and oppression, and which has since 1994, like the German courts after World War II, sought to establish a Rechtsstaat, a constitutional state, premised on a rejection of the injustices in its past.

Before turning to the Nazi law aspect of the debate, I need to give you a little more background on Hart's argument. As mentioned above, Hart sought to defend the proposition that whether law is valid is a different and separate question to whether it is morally sound.

10 Lon L Fuller, The Law in Quest of Itself (Northwestern University Press 1940) 3. See further David Luban, Legal Ethics and Human Dignity (Cambridge University Press 2007) 103.

11 Lon L Fuller, The Morality of Law (rev edn, Yale University Press 1969) 106.

12 Robert S Summers, Lon L Fuller (Stanford University Press 1984) 31, cited in Lacey (n 4) 35. 
Hart traced the roots of this distinction back to the utilitarian philosophers, John Austin and Jeremy Bentham. The consequence of the distinction, according to Bentham and Austin, was the fact that a rule was immoral did not mean it was not a rule of law; and the fact that a rule was morally desirable did not automatically make it a rule of law. Consistent with this approach, Bentham urged citizens to 'obey punctually, [but] censure freely'. ${ }^{13}$ Bentham, Hart recalled, argued that the conflation of law and morals held two dangers: the error of the anarchist who thought he was 'free not merely to censure but to disregard' the law, ${ }^{14}$ and the danger of the reactionary who argues that this is the law, and therefore this is what ought to be-an approach described inimitably by Bentham as 'obsequious quietism'. ${ }^{15}$

Hart then noted that acceptance of the distinction between law and morality had waned in the twentieth century. There were various reasons for this, he noted, and he considered in particular two strands of thought that were challenging the legitimacy or sustainability of the distinction. First, he considered the challenge launched by the American Realist School, Karl Llewellyn and Jerome Frank, to the determinacy of legal text, and the task of legal interpretation, ${ }^{16}$ a centrally important question for lawyers, though one beyond the scope of my remarks here.

Then Hart considered the challenge that arose, as he memorably described it, from 'the testimony of those who have descended into Hell'. ${ }^{17}$ He was speaking of Nazi Germany, and the jurisprudence of Gustav Radbruch in particular. Radbruch, a German legal scholar, had considered himself to be a legal positivist before he witnessed the horrors of the Third Reich and the conduct of judges and lawyers in interpreting and applying Nazi law. Radbruch concluded that the doctrine of legal positivism, summed up as Gesetz ist Gesetz ('law is law'), had contributed to the impunity with which the Nazi government had implemented evil and

13 Jeremy Bentham, 'A Fragment of Government' in The Works of Jeremy Bentham, vol I (Bowring ed, William Tait 1859) 230, quoted in Hart (n 3) 597.

Hart (n 3) 598. 
unjust laws. ${ }^{18}$ This led Radbruch to argue that lawyers and judges should denounce immoral laws, not only as immoral, but as not law at all. ${ }^{19}$

Hart was sympathetic to the circumstances that had given rise to Radbruch's argument, but he thought that the argument was wrong. In his view, whether laws are moral does not determine their validity, but only determines the moral obligation to obey them. 'If with the Utilitarians we speak plainly, we say that laws may be law but too evil to be obeyed. ${ }^{, 20}$ As an illustration of the potential consequences of Radbruch's argument, Hart referred to a case that has come to be known as that of the 'grudge informer'. The case concerned a woman who had denounced her husband for insulting remarks he had made to her about Hitler. She was under no legal duty to report the remarks, but the consequence of her report was that her husband was arrested and sent to the eastern front. In 1949, she was prosecuted in West Germany for an offence of depriving a person of his freedom, a crime under the Strafgesetzbuch of 1871. Her defence was that she had not committed a crime, since her informing on her husband had been lawfully authorised by the Nazi statute criminalising his remarks. ${ }^{21}$ But, according to Hart, the German Court of Appeal had held that the Nazi statute was 'contrary to sound conscience and sense of justice of all decent human beings' and so could not found a defence. ${ }^{22}$

In fact, it subsequently became clear that Hart was wrong in his account of the German Court's reasoning. ${ }^{23}$ The Court held that the action of the woman was illegal not because the law was inconsistent with natural law but because her action would have been condemned by 'the opinion of ethics and decency that survived among wide swaths of the German people even during national socialist rule'. ${ }^{24}$ The Court reasoned that popular opinion would have reached this conclusion after considering that the woman had voluntarily made a report that

18 Gustav Radbruch, 'Gesetzliches Unrecht und übergesetzliches Recht’ (1946) 1 Süddeutsche Juristen-Zeitung 105, cited in Hart (n 3) 617.

$19 \quad$ Hart (n 3) 617-18.

20 ibid 620.

21 The statute is quoted and discussed below at $\mathrm{n} 41$.

22 Hart (n 3) 619.

23 HO Pappe, 'On the Validity of Judicial Decisions in the Nazi Era' (1960) 23 Modern Law Review 260; David Dyzenhaus, 'The Grudge Informer Case Revisited' (2008) 83 New York University Law Review 1000 . 
she was not obliged to make, aware of its serious consequences, and where 'the reported utterances spoke the truth'.25

Hart noted that ' $[\mathrm{t}]$ he unqualified satisfaction with this result [that the court held that law to be invalid] seems to me to be hysteria' ${ }^{26}$ He thought that the German court should not have found the Nazi law invalid. Instead, he thought that the woman should either have gone unpunished (which Hart accepted was an unattractive result), or retrospective legislation should have been enacted to address the situation. 'Odious as retrospective criminalisation and punishment may be', Hart said, this approach 'would at least have had the merits of candour' ${ }^{27}$ He continued:

It would have made plain that in punishing the woman a choice had to be made between two evils, that of leaving her unpunished and that of sacrificing a very precious principle of morality endorsed by most legal systems. Surely if we have learned anything from the history of morals, it is that the thing to do with a moral quandary is not to hide it. Like nettles, the occasions when life forces us to choose between the lesser of two evils must be grasped with the consciousness that they are what they are. The vice of this use of the principle that, at certain limiting points, what is utterly immoral cannot be law ... is that it will serve to cloak the true nature of the problems with which we are faced and will encourage the romantic optimism that all the values we cherish ultimately will fit into a single system, that no one of them has to be sacrificed or compromised to accommodate another ... This is surely untrue ... . ${ }^{28}$

Fuller disagreed with Hart that law and morality could or should be separated. Fuller's approach is founded on his idea that law deserves loyalty or fidelity, and for it to deserve fidelity it must

... represent a human achievement; it cannot be a simple fiat of power ... If laws, even bad laws, have a claim to our respect, then law must represent some general direction of human effort that we can understand and describe, and that we can approve in principle even at the moment that it seems to us to miss its mark. ${ }^{29}$

The respect we owe law arises at least in part from certain rules that are internal to a legal system itself, that need to be respected. ${ }^{30}$ These key principles were subsequently spelt out in his book The Morality of Law: that the law be generally applicable; published; clear;

25

$26 \quad$ Hart (n 3) 619.

27 ibid.

ibid.

ibid 619-20.

Fuller, ‘Positivism and Fidelity to Law’ (n 3) 632.

ibid 644-48. This fourth part of his essay is titled 'The Morality of Law Itself'. 
prospective not retroactive; logically consistent or coherent; possible to obey; and constant over time; and that there be congruence between rules and their application. ${ }^{31}$ There is a considerable overlap between these principles and principles variously referred to as the rule of law, the principle of legality, or the Rechtsstaat.

Fuller argued that if a legal system observes these principles, which he calls the inner morality of law, the legal system is more likely to establish moral rules than if it does not. He acknowledged that he cannot establish this claim: 'I shall have to rest on the assertion of a belief that may seem naïve, namely, that coherence and goodness have more affinity than coherence and evil. ${ }^{32}$ The claim, at the end of day, is an empirical claim, not a normative one, which probably cannot be established without careful empirical study. It is important here to recognise that Fuller's claim, although he regards it as a natural law claim, is quite different to other natural law claims which at least historically focussed on the substance, not the method, of law, and suggested that there was a higher realm of law, often closely associated with religious belief, with which temporal law must comply for it to be valid.

When Fuller turned to the question of Nazi law, he subtitled his response, 'The problem of restoring respect for law and justice after the collapse of a regime that respected neither' ${ }^{33}$ The way Fuller frames the question illustrates that here is one of the central points in the debate where he and Hart are thinking about the question differently. Fuller is thinking less about law in a conceptual sense, as Hart was, but more in a sociological sense, as a social enterprise that is dynamic and carried forward by human actors. The problem of restoring respect for law, Fuller said, was a 'frightful predicament', caused by the fact that Nazi laws had been egregiously immoral and evil, yet they had been in operation and their consequences could not be simply ignored. ${ }^{34}$ It was not possible, he observed, to outlaw all that had happened over the preceding twelve years, but the consequences of Nazi perversity had nevertheless to be eradicated. ${ }^{35}$ How resonant this problem is to a South African lawyer.

Fuller, The Morality of Law (n 11) ch 2.

ibid 648.

ibid.

ibid. 
In considering Nazi law, Fuller starts by stating that 'Professor Hart seems to assume that the only difference between Nazi law and, say, English law is that the Nazis used their laws to achieve ends that are odious to an Englishman' ${ }^{36}$ Fuller thinks this is the wrong starting point. And he identifies a range of devices used by the Nazis to illustrate that the problem with Nazi law lay not only in its content, but also in its process and method.

First, he notes the practice of retroactive ratification of unlawful actions, including the 'Röhm purge' in 1934, after which Hitler declared that in conducting the purge he had acted as the supreme court of the German people. ${ }^{37}$ Then Fuller notes the rumoured Nazi practice of adopting secret laws, where conduct was ordered in terms of a law that was never published. ${ }^{38}$ He also notes the practice, 'when legal forms became inconvenient', that they would be bypassed by the party in the streets. ${ }^{39}$ These three examples illustrate, in Fuller's view, the fact that Nazi law did not comply with the internal morality of law. It is perhaps not surprising, then, that later in his essay he concludes that 'there is nothing shocking in saying that a dictatorship which clothes itself with a tinsel of legal form can so far depart from the morality of order, from the inner morality of law itself, that it ceases to be a legal system'. ${ }^{40}$

Fuller's consideration of the grudge informer case starts by citing the relevant statutes. I am only going to refer briefly to the second, 1934 statute, which provides:

Whoever publicly makes spiteful or provocative statements directed against ... the leading personalities of the nation or of the [Nazi] Party, or toward measures taken or institutions established by them, and of such a nature as to undermine the people's confidence in their political leadership, shall be punished by imprisonment. ${ }^{41}$

The provision then continues to state that the prosecution for such utterances shall be on the order of the Minister of Justice, with the advice and consent of the representative of the Leader, and that the Minister of Justice, again with the consent and advice of the Leader, shall determine

\footnotetext{
36 ibid 650.

37 ibid.

$38 \quad$ ibid 651.

$39 \quad$ ibid 652.

40 ibid 660.

41 Article 2(1) of the Law against Malicious Attacks on the State and the Party and for the Protection of the Party Uniform (20 December 1934), Reichsgesetzblatt I 1934, 1269, quoted in Fuller (n 3) 654.
} 
who shall belong to the class of leading personalities. ${ }^{42}$ Thus the legislation does not tell those bound by it the names of those they may not criticise; that is a matter to be determined by the Minister of Justice. Fuller, rightly, calls this piece of legislation a 'monstrosity ... overlarded and undermined as it is by uncontrolled administrative discretion' ${ }^{43}$

Fuller went on to criticise Hart's censure of the German courts. ${ }^{44}$ He felt that Hart's solution of a retroactive statute was no solution. The courts had to address the grudge informer case without waiting for a statute. Fuller argued that the 'the true nature of the dilemma confronted by Germany in seeking to rebuild her shattered legal institutions' meant that Germany

had to restore both respect for law and respect for justice. Though neither of these could be restored without the other, painful antinomies were encountered in attempting to restore both at once ... Of course no pat formula can be derived from this phrasing of the problem. ${ }^{45}$

Finally, (and perhaps somewhat contradictorily) Fuller noted that he too-indeed as had Radbruch-would have preferred the solution proposed by Hart, to enact retroactive legislation. ${ }^{46}$ He preferred it because, he said, it would symbolise a sharp break with the past and make it possible to plan more effectively for a recovery of the ideal of fidelity to law. ${ }^{47}$

The disagreement between Fuller and Hart on Nazi law thus centres on two related questions: First, was Nazi law valid? Hart thought it was valid, regardless of its immoral content. This argument was a necessary one for Hart's overall argument: that the question whether law is valid is separate from the question whether its contents are moral. On the other hand, Fuller thought that Nazi law should perhaps be considered invalid, given the extent of the infringement by Nazi law of the principles of the internal morality of law. For Fuller, this was an evaluative question, not one that could be answered by bright-line conceptual distinctions. He thought that a legal system that strays too far from the principles of the inner morality of law may, in the end, not properly be considered law at all. Whether this was so

\footnotetext{
42 Articles 2(3) and (4).

43 Fuller, 'Positivism and Fidelity to Law' (n 3) 654.

$44 \quad$ ibid 655.

45 ibid 657.

46 ibid 661.

47 ibid.
} 
was, for Fuller, a matter of degree. Given the extent to which Nazi law had violated the internal morality of law, Fuller was prepared to accept that it was not law at all.

The second, related question is what should the post-war German courts do in relation to Nazi law? Again Hart thought that the courts should accept that Nazi law had been valid at the time that it was in force and that courts should not assert otherwise. Any different response should be contained in legislation. Fuller was less certain. He thought this was a complex question, one which needed to be answered in light of the need in Germany to rebuild shattered institutions, to re-establish fidelity to law, and of the central role courts should perform in achieving these goals. Moreover, he thought that these tasks did not admit of 'pat' solutions, ${ }^{48}$ but raised painful antinomies that needed to be accommodated in the reasoning of the courts. He thought that Hart's answer that courts should not invalidate Nazi law retroactively, but that legislatures should, did not avoid the clash of moral principles. It merely restated the question as to 'who should do the dirty work, the courts or the legislature'. ${ }^{49}$

In addition to their different answers to these questions, the style of their reasoning is quite different. Hart asserts that it is a primary obligation of jurisprudence to be both clear and candid. ${ }^{50}$ And his answers to both questions are clear and candid. This perhaps is not surprising because Hart chose the subject matter of the debate, and addressing the Nazi law argument was core to his argument. He did not shrink from the difficult conclusions to which his argument led him, at least in relation to the validity of Nazi Law. ${ }^{51}$ Fuller on the other hand did not provide cut and dried answers to the questions. He did not think there were clear answers: 'the existence of a legal system, even a bad or evil legal system, is always a matter of degree', 52 he said, and building a new jurisprudence on an evil past is complex and does not admit of 'pat' solutions.

ibid 657, quoted at $\mathrm{n} 45$ above. ibid 649.

50 Hart (n 3) 593, 619-20.

51 But see Jeremy Waldron's analysis of Hart's wavering in relation at least in answering questions as to whether there is a relationship between the principles of legality (or the internal morality of law) and law itself; and whether there is a relationship between those principles and norms such as justice, human rights and the common good: Jeremy Waldron, 'Positivism and Legality: Hart's Equivocal Response to Fuller' (2008) 83 New York University Law Review 1135.

52 Fuller, 'Positivism and Fidelity to Law' (n 3) 646. 
Bear these differences between Fuller and Hart in mind, as we turn to consider their relevance to the life of Bram Fischer.

\section{Bram Fischer}

Most of you know Bram's story well, so I am not going to repeat it here. ${ }^{53} \mathrm{I}$ am going to turn straight to his arrest in September 1964, on a charge of being a member of the Communist Party, just months after the tragic death of his wife Molly.

That charge, of course, was based on the Suppression of Communism Act 44 of 1950. The political roots of that Act lay in the 1948 elections in South Africa, which were a critical turning point in South Africa's history. Almost immediately after the 1948 elections, the new Nationalist Prime Minister DF Malan had appointed a commission of inquiry to investigate the Communist Party. The Commission reported that the Party was 'a danger to our national life, to our democratic institutions and to our Western philosophy', ${ }^{54}$ and in 1950 Parliament enacted the Suppression of Communism Act. The Act defined communism extremely broadly, catching within its net 'any related form of that doctrine [communism] ... which aims at bringing about any political, industrial, social or economic change within the Union [of South Africa] by the promotion of disturbance or disorder' or 'which aims at the encouragement of feelings of hostility between the European and non-European races of the Union'. ${ }^{55}$ Just before the Act came into force, given the direct threat to it, the Communist Party dissolved. ${ }^{56}$

But the Suppression of Communism Act not only outlawed the Communist Party, ${ }^{57}$ it also authorised a range of extremely repressive measures-harbingers of what was to come in the following decades. It enabled the Governor-General to declare organisations 'unlawful organisations' if he (never she) was satisfied that the organisation professed communism or propagated its principles ${ }^{58}$ (defined broadly as referred to before). The consequences of being

There are two excellent biographies of Bram Fischer: Stephen Clingman, Bram Fischer: Afrikaner Revolutionary (David Philip 1998) and Martin Meredith, Fischer's Choice: A Life of Bram Fischer (Jonathan Ball 2002).

Quoted in Meredith (n 53) 33. 
declared an unlawful organisation were to all intents and purposes fatal for the organisation. It was a criminal offence to continue to serve as a member of such an organisation, to contribute and solicit subscriptions or other forms of funding for the organisation, and to take part in any activity of the organisation. ${ }^{59}$ These offences carried a maximum penalty of ten years. ${ }^{60}$ Property of the organisation was forfeit, ${ }^{61}$ and if the organisation was registered in terms of any law, the Act provided that it would 'cease to be registered'. ${ }^{62}$ Any challenge to a proclamation declaring an organisation unlawful had to be brought within 14 days of the date of the proclamation. ${ }^{63}$

The Act also provided for the compilation of a 'list of persons' who had been officebearers, members or active supporters of the Communist Party or any unlawful organisation (although the Act did provide for people to be given an opportunity to object prior to their name being included in the list). ${ }^{64}$ The Minister of Justice could by notice in writing require any person who 'is a communist' or who has been convicted of an offence under the Act, or a 'listed' person, to comply with instructions given by the Minister, ${ }^{65}$ to resign as an officebearer of any organisation, ${ }^{66}$ and not to serve as member of Parliament or provincial council, or the legislative assembly in South West Africa. ${ }^{67}$ The Governor-General could without notice to anyone prohibit the printing or dissemination of any publication that he was satisfied propagated the principles of communism, or promoted its spread, or any publication that is published by an unlawful organisation. ${ }^{68}$ Finally, the Act provided that the Minister could prohibit gatherings if there was 'reason to believe that the achievement of any of the objects of communism would be furthered' by the gathering, ${ }^{69}$ and for the Minister to issue a notice

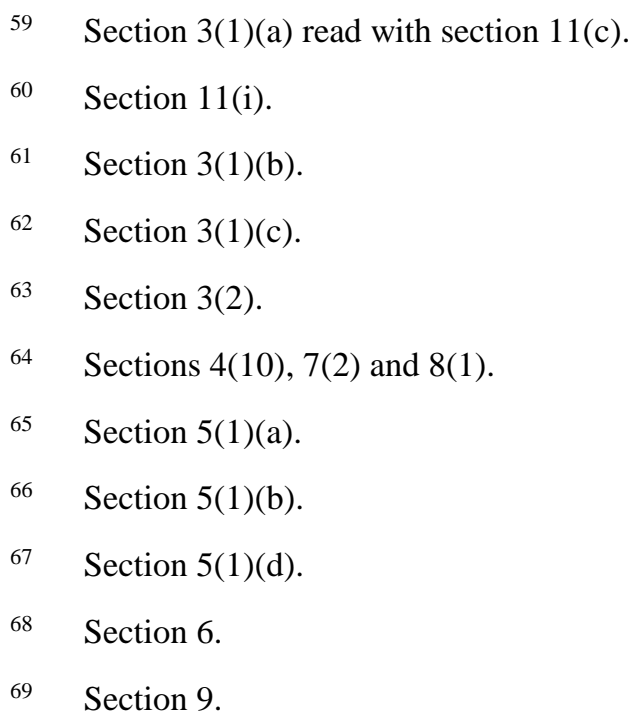


prohibiting identified people from being in particular areas for a period determined by the Minister. ${ }^{70}$

The legislation was thus deeply repressive of political dissent. It provided for the banning of organisations, of gatherings, and of publications, and for orders preventing people from participating in the activities of organisations. The lynchpin of the legislation was a definition of communism that sparked comment even from Judge Rumpff, not a famous opponent of apartheid, when he convicted 20 leaders of the liberation movements, including Nelson Mandela and Walter Sisulu, of charges arising from the Act. He found them to be guilty of 'statutory communism', something he noted that 'has nothing to do with communism as it is commonly known'. ${ }^{71}$

And the legislation was energetically and harshly applied. Both Bram and his wife Molly were restricted under it. ${ }^{72}$ In a statement issued in August 1954, after he had been ordered to resign both as a member and as Secretary-General of the African National Congress, Walter Sisulu asserted that the primary aim of the Suppression of Communism Act 'was to silence all opposition to the tyranny of the Malan government, especially from non-European organisations'. ${ }^{73}$ He noted that almost the entire national executive of the African National Congress had been served with restrictions under the Act, listing their names in a litany of struggle stalwarts: Moses Kotane, JB Marks, Mandela, Tloome, Njongwe, Mji, Molema, Bopape, Matji, Tshume, Matthews, Ngwevela, Mhlaba, Motshabi, Ngwentshe, Lengisi; and then the leaders of the Indian Congress, Dadoo, Cachalia, Nana Sita; and of the Congress of Democrats, Fischer, Williams, Kahn, Bernstein, Watts, Bunting, Hodgson. And the litany went on.

Can you hear the echoes of that Nazi law which criminalised criticism of the Nazi leaders in the Suppression of Communism Act? Like the 1934 Nazi legislation, the South African Act conferred wide discretionary powers on the Minister and Governor-General-power to

70 Section 10(1).

71 Quoted in Meredith (n 53) 41.

72 Meredith (n 53) 66.

73 WM Sisulu, Statement after being ordered to resign from membership of the ANC and from his position as Secretary-General (20 August 1954) <www.anc.org.za/content/statement-wm-sisulu-after-being-orderedresign-membership-anc-and-his-position-secretary> accessed 16 February 2017. 
determine which organisations should be declared unlawful, which publications should be permitted and which actions they should prohibit. The Suppression of Communism Act of 1950 bore the same hallmarks as the 1934 legislation in Germany.

Bram was arrested at chambers and was charged under the Suppression of Communism Act along with 13 others of being a member or office bearer of the Communist Party. ${ }^{74}$ On 24 September 1964, Bram applied for bail, including permission to travel to London to appear before the Privy Council. The state opposed his application. Bram told the magistrate that he had no intention of leaving the country permanently, that he did not intend to avoid prosecution, and that he was a senior counsel who intended to travel overseas to represent clients before the Privy Council. After deliberating the magistrate granted bail, stating that Bram was 'a son of our soil and an advocate of standing in this country'. ${ }^{75}$

So, with the permission of the court, Bram left the country to argue an appeal before the Privy Council. Despite the exhortations of friends and colleagues in London of the peril he faced, he returned to stand trial. ${ }^{76}$ The prosecution case was based on the evidence of Piet Beyleveld, an old friend and colleague of Bram's who had played a leading role in the Communist Party and at the Congress of the People in 1955 - an act of betrayal which shocked the accused deeply_and Gerald Ludi, a member of the Security Police who had infiltrated both the Congress of Democrats and the Communist Party. ${ }^{77}$ Once their evidence had been led, it became clear that the accused were likely to be convicted. And in January 1965, Bram made the momentous decision to forfeit his bail and go underground.

He provided a statement for the Court that was read out by his counsel, Harold Hanson. It read:

I wish you to inform the Court that my absence, though deliberate, is not intended in any way to be disrespectful. Nor it is prompted by any fear of the punishment which might be inflicted on me. ... I have not taken this step lightly. ${ }^{78}$

He continued:

74

Meredith (n 53) 110.

ibid 111.

ibid 112-13.

ibid 113-14.

Letter from Bram Fischer to the Supreme Court (22 January 1965), quoted in Clingman (n 53) 355-56. 
Cruel, discriminatory laws multiply each year, bitterness and hatred of the Government and its laws are growing daily. No outlet for this hatred is permitted because political rights have been removed. ... Unless this whole intolerable system is changed radically and rapidly, disaster must follow. ... To try to avoid this becomes a supreme duty, particularly for an Afrikaner, because it is largely the representatives of my fellow Afrikaners who have been responsible for the worst of these discriminatory laws. ${ }^{79}$

Inevitably, a warrant was issued for Bram's arrest when he did not appear in court. Shortly afterwards, and to Bram's great shock, the Bar Council launched proceedings to have him struck from the roll. ${ }^{80}$ Bram wrote to his lawyer to explain his basis for opposing this application:

I assume that the sole reason for the decision is that I deliberately absented myself from my trial and estreated my bail....

The principle upon which I rely is a simple one, firmly established in South Africa legal tradition. Since the days of the South African War, if not since the Jameson Raid, it has been recognised that political offences, committed because of a belief in the overriding moral validity of a political principle, do not in themselves justify the disbarring of any person from practising the profession of the law. Presumably this is because it is assumed that the commission of such offences has no bearing on the professional integrity of the person concerned. ...

When an advocate does what I have done, his conduct is not determined by any disrespect for the law nor because he hopes to benefit personally by any 'offence' he may commit. On the contrary it requires an act of will to overcome his deeply rooted respect of legality, and he takes the step only when he feels that, whatever the consequences to himself, his political conscience no longer permits him to do otherwise. He does it not because of a desire to be immoral, but because to act otherwise would for him be immoral. ${ }^{81}$

It was argued by his counsel on Bram's behalf that the estreatment of bail was not related to his conduct as an advocate, and should not be stigmatised as dishonourable. The Court disagreed. ${ }^{82}$ It held that Bram had used his status as senior counsel to obtain bail and had given a solemn assurance that he would stand trial-conduct, the Court concluded, that was dishonourable. ${ }^{83}$ The Court added that if it were to treat the conduct as venial, it would have a 'deplorable' effect on the administration of justice, as it would suggest that those released on

79 ibid.

Meredith (n 53) 124.

Letter from Bram Fischer to Harold Hanson (4 February 1965), quoted in Clingman (n 53) 369-70 and Meredith (n 53) 124-25.

Society of Advocates of SA (Witwatersrand Division) v Fischer 1966 (1) SA 133 (T).

ibid 136. 
bail were entitled to consider they could estreat their bail without consequence. ${ }^{84}$ Finally, the Court noted that Bram's own letter suggested he was no longer prepared to conform to the laws of the country. Were the Court to allow Bram to remain on the roll, De Wet JP reasoned, the Court would not be fulfilling its obligation of upholding and enforcing the laws of the country. ${ }^{85}$ So on 2 November 1965, Bram's name was struck from the roll of advocates.

Some months later he was convicted of being a member of the Communist Party and sabotage and in May 1966 he was sentenced to life imprisonment. ${ }^{86}$ Like Mandela in the Rivonia Trial, Bram gave a speech from the dock in his trial. In it he said:

I accept the general rule that for the protection of a society laws should be obeyed. But when the laws themselves become immoral, and require the citizen to take part in an organised system of oppression — if only by his silence or apathy — then I believe that a higher duty arises. This compels one to refuse to recognise such laws. The laws under which I have been prosecuted were enacted by a wholly unrepresentative body, a body in which three-quarters of the people of this country have no voice whatever. These laws were enacted, not to prevent the spread of communism, but for the purpose of silencing the opposition of the large majority of our citizens to a government intent upon depriving them, solely on account of their colour, of the most elementary human rights: of the right to freedom and happiness; the right to live together with their families wherever they might choose; to earn their livelihoods to the best of their abilities, and to rear and educate their children in a civilised fashion; to take part in the administration of their country and to obtain a fair share of the wealth they produce; in short, to live as human beings. My conscience does not permit me to afford these laws such recognition as even a plea of guilty would invoke. ${ }^{87}$

\section{How Bram Fischer illuminates the Hart-Fuller debate}

There are at least two separate aspects to the history of Bram's conviction and his striking off that raise issues that resonate with the Hart-Fuller debate I discussed earlier. Each needs to be viewed separately. The first was Bram's continued membership and activities in the Communist Party, in contravention of the Suppression of Communism Act. It was that membership and those activities that were the centrepiece of his trial, upon which his former comrade Beyleveld testified. And it was of that membership and of those activities that Bram was convicted and then sentenced to life imprisonment. Bram's own statement from the dock,

ibid 136-37.

ibid 137.

Meredith (n 53) ch 13.

Quoted ibid 139-40. The statement is also available on South African History Online <v1.sahistory.org.za/pages/library-resources/speeches/bram-fischer/1966_what-idid-right.htm> accessed 14 February 2017. 
quoted above, makes clear that he thinks the law under which he is being prosecuted is an immoral law that he could not in good conscience recognise.

Here, Hart would no doubt say that the Suppression of Communism Act was a valid law, albeit immoral, and that Bram in choosing to disobey it was exercising the moral choice that all citizens must. Bram had taken the view that the law, although law, 'was too evil to be obeyed'. ${ }^{88}$ This was a possibility that both Hart (and Bentham) acknowledged might come to pass, that 'the time might come in any society when the law's commands were so evil that the question of resistance had to be faced' ${ }^{89}$ And this is what Bram did.

Fuller, of course, would have viewed the question differently. He would have looked closely at both the text of the Suppression of Communism Act, and at the broader context of the legal system, as he did with the grudge informer case in Germany. He would have done so 'to inquire how much of a legal system survived the general debasement and perversion of all forms of social order ... and what moral implications this mutilated system had for the conscientious citizen forced to live under it'. ${ }^{90}$ He would have analysed whether the Act was generally applicable, published, clear, prospective not retroactive, logically coherent, possible of being obeyed, and constant over time, and whether there was a congruence between its rules and their application. He would no doubt, as he was in the case of the 1934 Nazi legislation, ${ }^{91}$ have been dismayed by the sweeping discretion conferred upon the Governor-General and the Minister of Justice, and would have considered that discretion to be inconsistent with the internal morality of law. Fuller's assessment would have been made in the first place to decide, not whether the Suppression of Communism Act was a valid law or not, but whether it was an Act that should attract citizens' fidelity. Fuller would have been concerned with the moral question that faced Bram: he would have recognised that a legal system based on the internal principles of law is ordinarily, as a matter of our moral commitment, entitled to fidelity, and that fidelity could only be abandoned in the face of a greater moral obligation. 
It is interesting that Bram seemed to have approached the question in the same way. He prefaced his speech from the dock with an acknowledgement of the moral obligation of fidelity to law, by saying:

I accept the general rule that for the protection of a society laws should be obeyed. But when the laws themselves become immoral, and require the citizen to take part in an organised system of oppression — if only by his silence or apathy—-then I believe that a higher duty arises. This compels one to refuse to recognise such laws. ${ }^{92}$

As Edwin Cameron pointed out in his Bram Fischer Lecture last year, 'the painstaking subjectivity’ of this declaration is clear. ${ }^{93}$ Bram was speaking for himself. And, as Edwin also pointed out, Bram's colleagues and protégés who chose to continue to practice public interest law under apartheid, defending those charged with political offences or faced with forced removals and supporting new organisations such as trade unions and civil society organisations, played an important role that continued till apartheid itself ended. ${ }^{94}$ But it must also be acknowledged that the choice made by those lawyers was for most not deeply personally harmful or damaging, unlike the moral choice that Bram made. The consequence of his moral choice was devastating for him and his family. It took him to prison for the rest of his life.

Hart's crisp response that whether the law is valid is a separate question to whether one has a moral duty to obey it is analytically clear, and largely indisputable. What Fuller points to, however, is a more complex and contingent question: if we do owe fidelity to law, when does it run out? When is it outweighed by other moral considerations such as those that Bram felt so intensely? Hart no doubt would say that these are questions of moral philosophy not within the frame of reference he set himself. And that we must accept. But for lawyers from a fractured legal system, such as South Africa, these urgent questions need answers, even if they admit of no glib conclusion. The clarity of analytical positivism, one of jurisprudence's 'sovereign virtues' according to Hart, ${ }^{95}$ here sheds little light on these dark quandaries. Fuller's less crystalline analysis acknowledges at least the painful antinomies, the inevitability of moral compromise and doubt that these questions raise. And in asserting the moral value of fidelity

See again $n 87$.

Edwin Cameron, 'Fidelity and Betrayal under Law' (2016) 16 Oxford University Commonwealth Law Journal 346, 353.

ibid 353-54.

See again Hart (n 3) 593. 
to law, he provides a crucial starting point for the difficult moral assessment that must be undertaken by each lawyer and each judge.

The second question is even more difficult. It is the question of Bram's striking off. It is clear that this application was primarily based on his estreatment of bail, following his return from London. Bram was deeply shocked when the Bar proceeded with an application to strike him off with alacrity, within days of his non-appearance in his criminal trial. He thought that in South African law 'political offences, committed because of a belief in the overriding moral validity of a political principle, do not in themselves justify the disbarring of any person from practising the profession of the law' ${ }^{96}$ He acknowledged that his action had required 'an act of will to overcome his deeply rooted respect of legality' and had only been taken because his political conscience no longer permitted him to do otherwise. ${ }^{97}$

The duty that lawyers have to be honest and open with a court is a deep rule of professional ethics. It is premised on the moral and ethical obligation of fidelity to law for lawyers. It is not an immoral rule in most circumstances. Hart, who says little of circumstance or context, would have said once again that the question of the rule's validity is independent of the moral obligation to obey, and would have left it at that. Fuller, much more sensitive to context, might have accepted that the moral duty to observe the ethical rules of the profession could be attenuated in a debased and perverted legal system. And yet he would also have cautioned that the very possibility of law would always be in grave peril once the obligation of fidelity to law is abandoned.

\section{Conclusion}

And so Bram's extraordinary story of courage and sacrifice enables us to reflect on the perennial questions raised by Hart and Fuller nearly 60 years ago. The complex question of the relationship between law and morality will never fade away. Hart's crisp answers remain clear and compelling, but Fuller's claim that law, being a human enterprise, requires our fidelity for it to flourish is a profound reminder of our moral and ethical obligations as lawyers, judges and citizens. The duty of fidelity to law provides a meaningful frame for the difficult ethical

\footnotetext{
$96 \quad$ See again $\mathrm{n} 81$.
}

97 ibid. 
decisions that lawyers and judges constantly face, even if that duty will not always be, as it was not for Bram, finally determinative of any decision.

Keeping Bram's memory alive in collegial conversation, in the law reports at the Legal Resource Centre and in the history of South Africa's struggle against apartheid will always remind us of both the duty of fidelity to law, and the fact that at times it conflicts with other moral obligations. Remembering the hard decisions Bram made will continually remind lawyers and judges that when we weigh our moral and ethical decisions, a 'deeply rooted respect of legality', as Bram put it, will always be an important, if not always determinative, weight in the scales.

\section{Author notes}

The author is the director of the Bonavero Institute of Human Rights at the University of Oxford and a former Justice of the Constitutional Court of South Africa. 